\title{
Prevalence of Toxoplasma gondii in common moles (Talpa europaea)
}

\author{
Inge M Krijger', Jan BWJ Cornelissen², Henk J Wisselink² and Bastiaan G Meerburg ${ }^{1 *}$
}

\begin{abstract}
Background: The prevalence of Toxoplasma gondii in common moles, Talpa europaea, was investigated in order to determine whether moles can serve as an indicator species for T. gondii infections in livestock.

Findings: In total, 86 moles were caught from 25 different sites in the Netherlands. Five different trapping habitats were distinguished: pasture, garden, forest, roadside, and recreation area. No positive samples (brain cysts) were found during microscopic detection $(n=70)$. Using the Latex Agglutination Test $(L A T)$, sera of 70 moles were examined, whereby no sample reacted with $T$. gondii antigen. Real Time-PCR tests on brain tissue showed 2 positive samples (2.3\%).

Conclusions: Because of the low number of positives in our study, the use of the common mole as an indicator species for livestock infections is currently not recommended.
\end{abstract}

Keywords: Parasite, Moles, Reservoir, Food safety, Outdoor farming, Wildlife, Indicator

\section{Findings}

Toxoplasma gondii is a zoonotic pathogen, which can infect a wide range of intermediate hosts [1-3]. The disease burden of clinical toxoplasmosis is high $[1,4-8]$ and the risk for human infection is considered substantial [9]. In farm environments [10,11] and especially in animal production systems with outdoor access for livestock a major risk emerges because of the coincidental uptake of oocysts or intermediate hosts [12]. If cats (definitive parasite hosts) that were not previously exposed to $T$. gondii consume infected intermediate hosts tissue (e.g. birds or rodents), they can start shedding oocysts which may disperse into the soil by precipitation [13] and be taken up by earthworms [14]. Earthworms carry infectious $T$. gondii [15-17], although from these studies it is unclear whether the parasite originated from the earthworms or the soil associated with them. Here, we test whether the common mole (Talpa europea), whose staple food consists of earthworms [18], can be an indicator species for T. gondii. Use of an indicator species would be beneficial as this reduces the need to obtain blood samples from livestock to measure $T$. gondii prevalence.

\footnotetext{
*Correspondence: Bastiaan.Meerburg@wur.nl

'Wageningen UR (University \& Research centre), Livestock Research,

P.O. Box 338, 6700 AH Wageningen, The Netherlands

Full list of author information is available at the end of the article
}

Moreover, moles are considered a pest and are regularly trapped because of their destructive behaviour. To our knowledge, only two studies have previously investigated T. gondii prevalence in common moles. In the first study, a case-report of a dead mole that carried $T$. gondii was presented [19]. In the second study, 7 of 18 common moles examined were found to be positive using a Modified Agglutination Test (MAT) [20].

In March 2013, 25 different sites in the Netherlands were surveyed using lethal mole traps. As the common mole is considered as a nuisance species, these animals had to be eliminated and in such cases no approval of the animal experimental ethics committee (DEC) is required according to Dutch law \& regulations. Trapping sites were distributed over 4 provinces: Zuid-Holland, Gelderland, Utrecht, and Overijssel (Figure 1). Five trapping habitats were distinguished: pasture, garden, forest, roadside, or recreation area. The origin of each mole was registered and the gender noted, except for the first samples (gender 'unknown'). Mole traps were checked daily and upon capture, moles were transported to the Central Veterinary Institute in Lelystad under cool conditions $\left(4^{\circ} \mathrm{C}\right)$ and dissected within $48 \mathrm{~h}$ in order to collect blood samples from the heart and brain samples. If moles could not arrive in the laboratory within $48 \mathrm{~h}$ after capture, they were frozen 


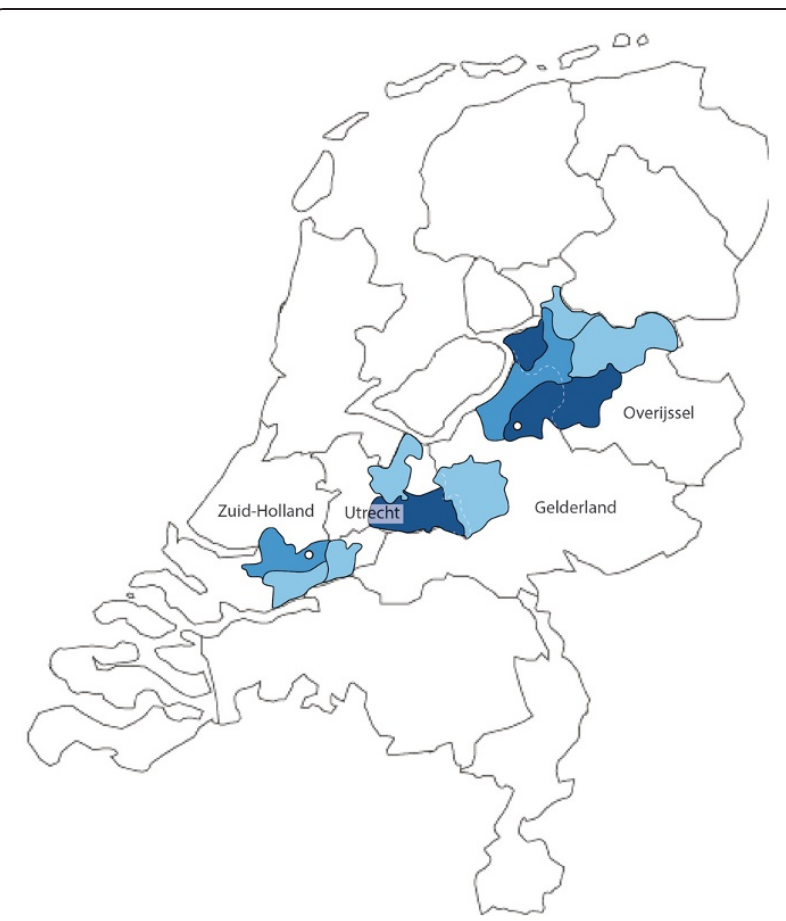

Figure 1 Trapping sites of common moles in the Netherlands classified to the postal code. Dark blue: $>10$ trapped moles, medium blue: $>5$ trapped moles, light blue: $<5$ trapped moles, white: no moles trapped. Circles (o): positive moles.

at $-18^{\circ} \mathrm{C}(\mathrm{n}=16)$ until they were dissected. The night before dissection, frozen moles were thawed at $4^{\circ} \mathrm{C}$.

Half of the brain of each non-frozen mole $(n=70)$ was homogenised after dissection using a cell strainer $(0.2 \mu \mathrm{M})$ and plunger with addition of $5 \mathrm{ml}$ PBS (phosphate buffered saline, $8.2 \mathrm{~g} \mathrm{NaCl}, 0.20 \mathrm{~g} \mathrm{KCL}, 1.15 \mathrm{~g} \mathrm{Na}_{2} \mathrm{HPO}_{4}$, $0.38 \mathrm{~g} \mathrm{KH}_{2} \mathrm{PO}_{4}$ per litre). In order to enrich the T. gondii cysts, $5 \mathrm{ml}$ Percoll (Sigma Aldrich, Zwijndrecht, the Netherlands) $30 \%$ gradient was added underneath the homogenised brain sample. After centrifuging this mixture $\left(1200 \mathrm{~g}\right.$ for $15 \mathrm{~min}$ at $\left.4^{\circ} \mathrm{C}\right)$, resuspended in PBS, a $25 \mu \mathrm{l}$ pellet was analysed using a light microscope $(20 \times)$, (Floating Technique [21]), according a modified protocol [22]. Frozen moles were not included in this analysis. DNA was extracted from homogenised brain tissue (the frozen samples were homogenised by using an ultra turrax) with the DNeasy Blood \& Tissue kit (Qiagen GMBH, Hilden, Germany), using a slightly adjusted protocol: glass homogeniser beads were added to the sample mixed by a vortex during $60 \mathrm{~s}$ to facilitate lysis, after which lysis buffer was added. Samples were then incubated at $56^{\circ} \mathrm{C}$ for $2.5 \mathrm{~h}$. Hereafter, the protocol of the test manufacturer was followed. The extracted DNA samples were stored at $-20^{\circ} \mathrm{C}$ until tested by Real-Time PCR. For serologic detection of both T. gondii IgG and IgM antibodies by direct agglutination, blood obtained from non-frozen mole hearts $(n=70)$ was tested with
Table 1 Overview of the trapping numbers and habitat types

\begin{tabular}{lllll}
\hline Habitat type & $\begin{array}{l}\text { \#Trapped (positives } \\
\text { between brackets) }\end{array}$ & Male & Female & $\begin{array}{l}\text { Unknown } \\
\text { gender }\end{array}$ \\
\hline Forest & 4 & 3 & 1 & 0 \\
Garden & $24(1)$ & 14 & 10 & 0 \\
Recreation area & $24(1)$ & 15 & 9 & 0 \\
Pasture & 32 & 20 & 8 & 4 \\
Roadside & 2 & 0 & 2 & 0 \\
\hline
\end{tabular}

Toxo-reagent kit RST701 (Mast Diagnostics Ltd, Bootle, UK), according to manufacturer's instructions. The test was performed in microtiter plates with U-shaped wells (Greiner Bio-One GmbH, Frickenhausen, Germany). Control and diagnostic sera were diluted $1: 8$, and titrated on the plates to a dilution 1:1024. In addition to control sera from the Toxo-reagent kit, internal positive cat and pig samples were used. The plates were analysed at normal daylight against a dark background. A positive reaction was noted when $T$. gondii agglutinated in the well until a dilution of 1:64 (1:32 will be regarded as doubtfull, $<32$ as negative) while a negative reaction was noted by sunken latex on the bottom of the well.

DNA samples were tested for $T$. gondii by a Real-Time PCR, oriented at target AF146527 [23]. Results were obtained using amplification primers Tox- 9 and Tox- 11 [24] as forward and reverse primers, respectively. Reactions were set up to a final volume of $25 \mu \mathrm{l}$ containing $1 \mu \mathrm{l}$ of DNA sample, $4 \mu \mathrm{l} \mathrm{H}_{2} \mathrm{O}$, and $20 \mu \mathrm{l}$ SYBR Green PCR Master Mix (Applied Biosystems, Paisley, UK). The Real-Time SYBR Green PCR reaction products were analysed with an ABI 7500 Real-Time PCR system with SDS Software Version 2.0.1 (Applied Biosystems, Paisley, UK) by a first cycle of $10 \mathrm{~min}$ of activation at $95^{\circ} \mathrm{C}$. The subsequent dissociation step consisted of: $95^{\circ} \mathrm{C} /$ $15 \mathrm{~s} ; 60^{\circ} \mathrm{C} / 1 \mathrm{~min} ; 95^{\circ} \mathrm{C} / 15 \mathrm{~s}$ for 40 cycles and the dissociation was measured stepwise, every $0.5^{\circ} \mathrm{C}$.

In total, 86 common moles were trapped (Tables 1 and 2). Samples were not evenly distributed over different trapping habitats (Figure 1). No positive samples (brain cysts) were found during the microscopic detection of the 70 non-frozen moles. Using the Latex Agglutination Test (LAT), sera of 70 moles were examined, whereby

Table 2 Results of the LAT and real time-PCR detection

\begin{tabular}{|c|c|c|c|c|c|c|c|c|}
\hline \multirow[t]{2}{*}{ Test } & \multicolumn{3}{|c|}{ Serology } & \multirow[b]{2}{*}{ Subtotal } & \multicolumn{3}{|c|}{ DNA } & \multirow[b]{2}{*}{ Subtotal } \\
\hline & $\sigma^{7}$ & 우 & $\begin{array}{l}\text { Unknown } \\
\text { gender }\end{array}$ & & $\sigma^{x}$ & 우 & $\begin{array}{l}\text { Unknown } \\
\text { gender }\end{array}$ & \\
\hline+ & 0 & 0 & 0 & 0 & 2 & 0 & 0 & 2 \\
\hline - & 44 & 22 & 4 & 70 & 50 & 30 & 4 & 84 \\
\hline Total & 44 & 22 & 4 & $70^{*}$ & 52 & 30 & 4 & $86^{*}$ \\
\hline
\end{tabular}

*Fresh, non-frozen moles were serologically tested. All moles (including the frozen) were DNA tested. 
only 1 sample (1.4\%) reacted with $T$. gondii antigen, at a 1:16 dilution (internal positive control samples reacted up to a 1:128 dilution). Using a cut off value of a dilution of 1:32 as questionable and a $>1: 64$ dilution as positive, this sample is considered as negative. The Real-Time PCR test on tissue samples revealed that 2 male moles were positive ( $\mathrm{Ct} 36.61$ and 36.57, respectively) for $T$. gondii $(2 / 86=2.3 \%)$. These moles were trapped in a garden and a recreation area.

In this study, $T$. gondii presence in moles was studied by different tests. Our LAT showed no sample that reacted with $T$. gondii antigen. For the Real-Time PCR brain tissue was used as this is the target organ in mice and it is also used for human prenatal diagnostics. Ctvalues were high for the two moles testing positive with Real-Time PCR (36.61 and 36.57, respectively), which means that little $T$. gondii DNA was present in the brain samples. Such high values could indicate false positives. However, in an earlier study, it was found that the Ctvalues of experimentally infected mice were around 20, whereas in naturally infected mice it varied between 35 and38 $[10,11]$. Therefore, we assume that the two samples found positive using Real-Time PCR were indeed positive. The positive samples from the Real Time-PCR were not positive using the LAT. A reason can be that it takes time for the animal to produce antibodies against $T$. gondii, whilst parasite DNA is already present.

In previous studies from France and Germany common moles were identified as possible intermediate hosts for $T$. gondii $[19,20]$. However, infection rates in our study (0$2.3 \%$, depending on the testing method) were significantly lower than the prevalence in the French study, where $39 \%$ of the moles from North-Eastern France tested positive [20].

Generally, animal age is positively related to the risk of T. gondii infection. In our study, the average age of trapped moles may have been lower, as most of them originated from habitats where moles are trapped regularly and so mainly juveniles are present. However, the age of the trapped moles was not determined. Because of the low number of positive samples in our study, no relation could be found between the prevalence of $T$. gondii in common moles, their gender or habitat type of the trapping location. Consequently, it must be concluded that the use of common moles as an indicator species is not yet feasible. Concerning habitat, we assumed beforehand that in areas where generally more cats are present (gardens and pastures) the infection rate would be the highest. However, due to the low number of positive specimens, it was not possible to prove this hypothesis statistically. In order to acquire more insight into this relationship, it would be necessary to increase the number of trapping locations and to test larger numbers of common moles. A comparison of T. gondii incidence in moles between countries that apply mainly indoor animal production systems (such as The Netherlands) and countries that apply outdoor animal production systems might be useful as well, as the low infection incidence could also be related to the type of production system. In conclusion, the use of common moles as an indicator species for $T$. gondii should be the subject of further study, preferably linked to detection of this pathogen in its diet (earthworms) and in near-by livestock.

\section{Competing interests}

The authors declare that they have no competing interests.

\section{Authors' contributions}

IK carried out the fieldwork, participated in the dissections, participated in the laboratory work and drafted the manuscript. JC carried out the immunoassays. HW participated in the design of the study. BM conceived of the study, and participated in its design and coordination and finalized the manuscript. All authors read and approved the final manuscript.

\section{Acknowledgements}

This study was supported by strategic research funds of Wageningen Livestock Research, Department of Livestock \& Environment. We would like to thank the participating mole trappers and the laboratory technicians.

\section{Author details}

${ }^{1}$ Wageningen UR (University \& Research centre), Livestock Research, P.O. Box 338, $6700 \mathrm{AH}$ Wageningen, The Netherlands. ${ }^{2}$ Wageningen UR (University \& Research centre), Central Veterinary Institute, P.O. Box 65, 8200 AB Lelystad, The Netherlands.

Received: 16 April 2014 Accepted: 15 July 2014

Published: 15 July 2014

\section{References}

1. Acha PN, Szyfres B: Zoonoses and communicable diseases common to man and animals. 3rd edition. Pan American Health Organization: Washington, DC; 2003.

2. Newell DG, Koopmans M, Verhoef L, Duizer E, Aidara-Kane A, Sprong H, Opsteegh M, Langelaar M, Threfall J, Scheutz F, Van der Giessen J, Kruse H: Food-borne diseases - the challenges of 20 years ago still persist while new ones continue to emerge. Int J Food Microbiol 2010, 139:S3-S15.

3. Opsteegh M: Toxoplasma gondii in animal reservoirs and the environment. In PhD thesis. Utrecht: Utrecht University, Faculty of Veterinary Medicine; 2011.

4. Dubey JP: Toxoplasmosis - a waterborne zoonosis. Vet Parasitol 2004, 126:57-72.

5. Montoya JG, Liesenfeld O: Toxoplasmosis. Lancet 2004, 363:1965-1976.

6. Petersen E: Toxoplasmosis. Sem Fetal Neonat Med 2007, 12:214-223.

7. Sroka J, Cencek T, Ziomko I, Karamon J, Zwolinski J: Preliminary assessment of ELISA, MAT, and LAT for detecting Toxoplasma gondii antibodies in pigs. Bull Vet Inst Pulawy 2008, 52:545-549.

8. Tenter AM, Heckeroth AR, Weiss LM: Toxoplasma gondii: from animals to humans. Intl J Parasitol 2000, 30:1217-1258.

9. Havelaar AH, Rosse F, Bubura C, Toetenel MA, Haagsma JA, Kurowicka D, Heesterbeek JAP, Van der Giessen JWB: Prioritizing emerging zoonoses in the Netherlands. PLoS One 2010, 5:E13965.

10. Kornalijnslijper JE, Rahamat-Langendoen JC, Van Duynhoven YTHP: Volksgezondheidsaspecten van veehouderijmegabedrijven in Nederland. Zoönosen en antibioticumresistentie. RIVM: Bilthoven; 2008.

11. Meerburg BG, De Craeye S, Dierick K, Kijlstra A: Neospora caninum and Toxoplasma gondii in brain tissue of feral rodents and insectivores caught on farms in the Netherlands. Vet Parasitol 2012, 184:317-320.

12. Kijlstra A, Meerburg BG, Bos AP: Food safety in free-range and organic livestock systems: risk management and responsibility. J Food Prot 2009, 72:2629-2637

13. Meerburg BG, Kijlstra A: Changing climate-changing pathogens: Toxoplasma gondii in North-Western Europe. Parasitol Res 2009, 105:17-24. 
14. Du F, Zhang Q, Yu Q, Hu M, Zhou Y, Zhao J: Soil contamination of Toxoplasma gondii oocysts in pig farms in central China. Vet Parasitol 2012, 187:53-56.

15. Bettiol S, Obendorf D, Nowarkowski M, Milstein T, Goldsmid J: Earthworms as paratenic hosts of toxoplasmosis in eastern barred bandicoots in Tasmania. J Wildlife Dis 2000, 36:145-148.

16. Frenkel JK, Ruiz A, Chinchilla M: Soil survival of Toxoplasma oocysts in Kansas and Costa Rica. Am J Trop Med Hyg 1975, 24:439-443.

17. Ruiz A, Frenkel JK: Intermediate and transport hosts of Toxoplasma Gondii in Costa Rica. The Am J Trop Med Hyg 1980, 29:1161-1166.

18. Funmilayo O: Distribution and abundance of moles (Talpa europaea L.) in relation to physical habitat and food supply. Oecol 1977, 30:277-283.

19. Geisel O, Breuer W, Minkus G, Hermanns W: Toxoplasmosis causing death in a common mole (Talpa europaea). Berl Munch Tierarztl Wochenschr 1995, 108:241-243.

20. Afonso E, Poulle ML, Lemoine M, Villena I, Aubert D, Gilot-Fromont E: Prevalence of Toxoplasma gondii in small mammals from the Ardennes region, France. Fol Parasitol 2007, 54:313-314.

21. Cornelissen AW, Overdulve JP, Hoenderboom JM: Separation of Isospora (Toxoplasma) gondii cysts and cystozoites from mouse brain tissue by continuous density-gradient centrifugation. Parasitol 1981, 83:103-108.

22. Fritz H, Bar B, Packham A, Melli A, Conrad PA: Methods to produce and safely work with large numbers of Toxoplasma gondii oocysts and bradyzoite cysts. J Microbiol Meth 2012, 88:47-52.

23. Homan WL, Vercammen M, De Braekeleer J, Verschueren H: Identification of a 200- to 300-fold repetitive 529 bp DNA fragment in Toxoplasma gondii, and its use for diagnostic and quantitative PCR. Int J Parasitol 2000, 30:69-75.

24. Reischl U, Bretagne S, Kruger D, Ernault P, Costa J-M: Comparison of two DNA targets for the diagnosis of toxoplasmosis by real-time PCR using fluorescence resonance energy transfer hybridization probes. BMC Inf Dis 2003, 3:7.

doi:10.1186/s13028-014-0048-0

Cite this article as: Krijger et al.: Prevalence of Toxoplasma gondii in common moles (Talpa europaea). Acta Veterinaria Scandinavica 2014 56:48

\section{Submit your next manuscript to BioMed Central and take full advantage of:}

- Convenient online submission

- Thorough peer review

- No space constraints or color figure charges

- Immediate publication on acceptance

- Inclusion in PubMed, CAS, Scopus and Google Scholar

- Research which is freely available for redistribution 